\title{
Powder and Gel for Gel Dosage Form
}

National Cancer Institute

\section{Source}

National Cancer Institute. Powder and Gel for Gel Dosage Form. NCI Thesaurus. Code C149771.

Powder and gel intended for the preparation of a gel (for cutaneous use) by mixing the powder in the gel. 